\title{
A STUDY ON ESTIMATION OF STATURE FROM FOOT LENGTH
}

1. Associate Professor,

Forensic Medicine, KEMU, Lahore.

2. Assistant Professor,

Forensic Medicine,

Avicena Medical college, Lahore.

3. Demonstrator,

Forensic Medicine, KEMU, Lahore.

4. Forensic Analyst, KEMU, Lahore.

5. Professor and Chairman,

Forensic Medicine, KEMU, Lahore

Correspondence Address:

Dr Arif Rasheed Malik

Associate Professor,

Forensic Medicine, KEMU, Lahore.

drarifrasheed@hotmail.com

Article received on:

13/04/2015

Accepted for publication:

28/04/2015

Received after proof reading:

06/05/2015
Dr. Arif Rasheed Malik1, Dr. Nasreen Akhter², Dr. Riasat Alï ${ }^{3}$, Dr. Ra'ana Farrukh, Prof. Dr. Khalid Aziz ${ }^{5}$

ABSTRACT... Stature is considered as one of the important and significant parameters for establishment of personal identity in forensic medical examination or anthropological studies. With the alarming increase in frequency of road and train accidents, floods, fire, deliberate mutilation, disfigurement and natural disasters, there is a need of studies that provide help to identify the deceased from fragmentary and dismembered human remains. In such situations, measurements of feet provide a reasonably good estimation about the stature of a person. The paucity of data that allowing reconstruction of stature from the dimensions of feet which highlights the need of such study. Objectives: 1). To determine the relationship between foot length and stature by calculating correlation coefficient. 2- To establish a regression model for estimation of stature from foot length in both male and female. Study design: Cross sectional survey study was carried out on the MBBS students of above 20 years of age of King Edward Medical University, Lahore. Sampling technique: Systematic sampling technique applied. Amongst the total students $(873)$ of $3^{\text {rd }}$ year, $4^{\text {th }}$ year and final year, every third student was included. Place of study: Department of Forensic Medicine \& Toxicology KEMU, Lahore. Duration of study: It was carried out in one year. Material and methods: The subject selection was based on following criteria: Inclusion criteria: The MBBS students of King Edward Medical University, Lahore irrespective of sex with age above 20 years were included in this study. Exclusion criteria: The subjects having diagnosed lower limb or foot deformities on clinical assessment were excluded. Results: A significant and positive correlation was found between foot length and stature in male and female subjects and regression equation was framed for both sexes. The correlation coefficient was highest between stature and foot length in males and females. Conclusion: Dimensions of feet can provide good reliability in estimation of stature. The correlation coefficient was highest between stature and foot length of both in males and females.

Key words: $\quad$ Foot, stature, length, correlation coefficient, identity, regression equation/ model.

Article Citation: Malik AR, Akhter N, Ali R, Farrukh R, Aziz K. A study on estimation of stature from foot length. Professional Med J 2015;22(5):632-639.

\section{INTRODUCTION}

Establishment of identity of a person is an important step in forensic medical examinations. The determination of stature is one of the parameter to achieve that objective. It has been vigorously studied internationally $1,2,3$, but unfortunately, there is no such study carried out in Pakistan.

The stature of a victim is commonly determined by measuring the long bone length and extrapolating the data. ${ }^{4}$ For that purpose, the long bones are cleaned and prepared which is a time consuming and tedious process. ${ }^{5}$

Therefore, researchers focused on measurements of hand and foot to determine sex and estimate stature. ${ }^{6}$

Foot length possesses a biological correlation with stature and it has been shown that the foot measurement provided important predictive information about the individual's stature ${ }^{7}$ and the reliability of prediction of stature from foot measurements was as high as that from long bones. ${ }^{8}$ As ossification and maturation in the foot occurs earlier than long bones, therefore, during adolescence, stature could be more accurately predicted from foot measurement as compared to that from the long bones. ${ }^{9}$ Furthermore, the measurement of foot length is very simple and 
accurate as compared to those of the long bones. ${ }^{10}$

In view of above description, a cross sectional survey study is conducted to determine the relationship between foot lengths and stature to improve the ability of investigating agencies in establishing identity.

\section{AIMS AND OBJECTIVES}

1- To determine the relationship between foot length and stature by calculating correlation coefficient.

2- To establish a regression model for estimation of stature from foot length in both male and female.

\section{MATERIALS AND METHODS}

This study was carried out on the MBBS students of above 20 years of age of King Edward Medical University, Lahore in the Department of Forensic medicine \& Toxicology. Total students in the list of $3^{\text {rd }}$ year, $4^{\text {th }}$ year and final year were 873 and every third student in the list was included the total sample size thus comprised of 291 students.

It was a cross sectional survey study with systematic sampling technique completed in one year duration.

The subject selection was based on following criteria:

\section{Inclusion criteria}

The MBBS students of King Edward Medical University, Lahore irrespective of sex with age above 20 years were included in this study.

\section{Exclusion criteria}

All those subjects who had recognized lower limb/foot deformities on clinical assessment were excluded from this study.

\section{DATA COLLECTING PROCEDURE}

291 MBBS students of KEMU fulfilling inclusion criteria were enrolled. Demographic information including name/gender was noted. Informed consent was taken.

For this study direct measurement technique was employed.

Thefootdimensionsweremeasuredindependently on left and right side of each individual using sliding caliper, with foot placed on a horizontal flat surface, while the subject was standing. The left foot was selected for measurements as per recommendation of the international agreement for paired measurements at Geneva. The maximum foot length was measured from acropodian (It is the most forwardly projecting point on the head of the 1st or 2nd toe whichever is larger when the subject stands erect) to pternion (It is the most backwardly projecting point on the heel when the subject is standing upright with equal pressure on both the feet).

The stature of the individual was measured standing erect in anatomical position using a standing measuring instrument. It was measured as the vertical distance between the vertex and the floor when the head was held in Frankfurt Horizontal (F.H) plane.

To ensure accurate result the measurements were taken at a fixed time between 2.00 to 4.00 P.M. to eliminate diurnal variation and was done by one person while sitting on low chair to avoid errors that could be caused by discomfort or individual differences.

All subjects were barefooted during measurements. To avoid errors, two readings were taken and mean was considered as final reading. All the findings were recorded in a proforma.

\section{STATISTICAL ANALYSIS/DATA ANALYSIS} Data were analyzed using SPSS 16.0. Age was expressed as Mean \pm SD and gender was expressed in the form of percentages. Pearson's correlation coefficient was used to determine the strength of relationship between foot length and stature. Regression model was used to estimate the stature both for male and female. Student's ' $\mathrm{t}$ ' statistic was used to evaluate the difference in 
stature with respect to sex. A p value $<0.05$ was considered as statistically significant.

\section{RESULTS}

\section{DESCRIPTIVE ANALYSIS}

Referring age, gender, localities, mean stature and mean left foot length of all subjects and of male and female subjects separately are shown in Table I, II, III respectively.

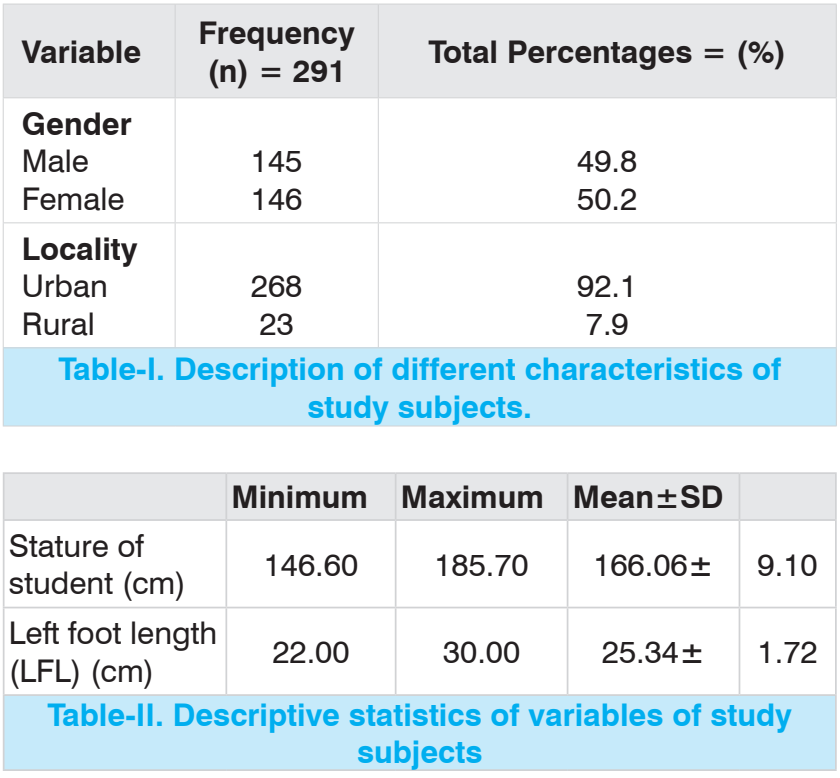

\begin{tabular}{|l|l|l|l|l|}
\hline Variables & & N & Mean \pm SD & P-value \\
\hline Stature of student & Male & 145 & $173.16 \pm 6.33$ & $<0.001$ \\
\hline Total =291 & Female & 146 & $159.02 \pm 5.00$ & \\
\hline Left foot length & Male & 145 & $26.52 \pm 1.419$ & $<0.001$ \\
\hline Total=291 & Female & 146 & $24.16 \pm 1.063$ & \\
\hline Table-III. Gender $\begin{array}{l}\text { wise descriptive statistics of variables } \\
\text { of study subjects }\end{array}$ &
\end{tabular}

\section{SECONDARY ANALYSIS}

A highly significant difference was observed in mean stature of male (173.16 \pm 6.33$)$ and female subjects $(159.02 \pm 5.007)$ as the $p<0.001$. A strong significant relationship was found between stature of all subjects and foot length $(r=0.807$, $p<0.001)$ Fig. 1.

The regression model of body stature on foot length in all subjects was fitted as (Table-IV).

The regression equation of body stature on foot length is showed as:-

$[Y($ Body Stature $)=58.101+4.261($ Foot Length $)]$

A significant high correlation was observed between actual body stature of subjects and estimated body stature using above said regression equation $(r=0.807, p<0.001)$.

\begin{tabular}{|l|l|l|c|}
\hline \multicolumn{1}{|c|}{ Variable } & $\begin{array}{c}\text { Regression } \\
\text { Coefficient }(\boldsymbol{\beta})\end{array}$ & \multicolumn{1}{|c|}{$\mathbf{t}$} & Sig. \\
\hline (Constant) & 58.101 & 12.455 & $<0.001$ \\
\hline Left foot length & 4.261 & 23.197 & $<0.001$ \\
\hline Table-IV. Regression Model of Body Stature on Left \\
Foot of all subjects
\end{tabular}

The regression model of body stature on foot length of male subjects was fitted as (Table-V).

The regression equation of body stature on foot length in male is showed as:-

$$
Y(\text { Body Stature })=104.455+2.591(\text { Foot Length })
$$

A significant high correlation was observed between actual body stature of male subjects and expected body stature using above said regression equation $(r=0.581, p<0.001)$.

\begin{tabular}{|l|l|l|r|}
\hline Variable & $\begin{array}{c}\text { Regression } \\
\text { Coefficient (B) }\end{array}$ & \multicolumn{1}{|c|}{ t } & Sig. \\
\hline (Constant) & 104.455 & 12.95 & $<.001$ \\
\hline Left foot length & 2.591 & 8.53 & $<.001$ \\
\hline
\end{tabular}

Table-V. Regression Model of Body Stature on Left Foot in Males

$Y($ Body Stature $)=104.455+2.591($ Foot Length $)$

The regression model of body stature on foot length of female subjects was fitted as (Table-VI).

The regression equation of body stature on foot length in female is showed as:-

$Y($ Body Stature $)=88.210+2.93($ Foot Length $)$ 
A significant high correlation was observed between actual body stature of female subjects and expected body stature using above said regression equation $(r=0.622, p<0.001)$.

\begin{tabular}{|c|c|c|c|}
\hline Variable & $\begin{array}{c}\text { Regression } \\
\text { Coefficient ( } \mathbf{\beta})\end{array}$ & $\mathbf{t}$ & Sig. \\
\hline (Constant) & 88.210 & 11.868 & $<.001$ \\
\hline Left foot length & 2.93 & 9.536 & $<.001$ \\
\hline Table-VI. Regression model of body stature on left foot \\
in females
\end{tabular}

$Y($ Body Stature $)=88.210+2.93($ Foot Length $)$

\section{CORRELATION BETWEEN FOOT LENGTH} AND BODY STATURE OF ALL SUBJECTS

A strong significant relationship $(r=0.807$, $p<0.001$ ) between foot length and body stature of all subjects is evident from Fig-1.

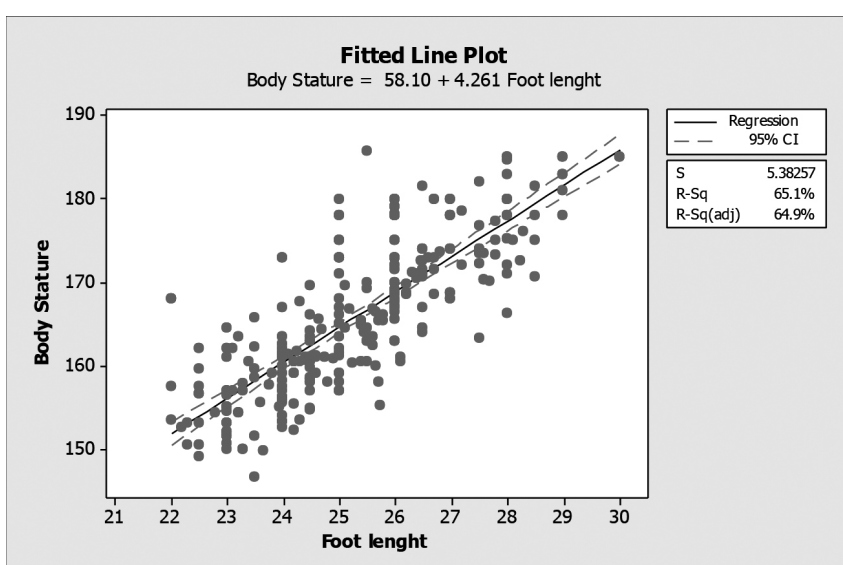

Fig-1. Scatter plot between body stature and foot length of all subjects.

There is positive and significant correlation between foot length and body stature of both male and female and graph shows a linear relationship between these two variables.

\section{CORRELATION BETWEEN FOOT LENGTH AND BODY STATURE OF MALES}

A strong significant relationship $(r=0.59$, $p<0.001$ ) between male foot length and body stature is depicted in Fig. 2.

There is positive and significant correlation between male foot length and body stature and graph shows a linear relationship between these two variables.

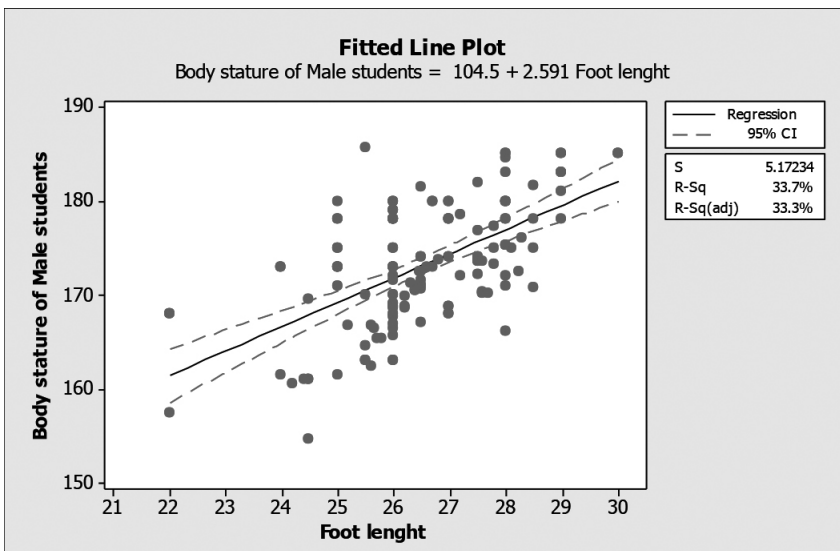

Fig-2. Scatter plot of left foot length and body stature of male subjects.

\section{CORRELATION BETWEEN FOOT LENGTH} AND BODY STATURE OF FEMALES

A strong significant relationship $(r=0.63$, $p<0.001$ ) between female foot length and body stature is shown in Fig. 3.

There is positive and significant correlation between female foot length and body stature and graph shows a linear relationship between these two variables.

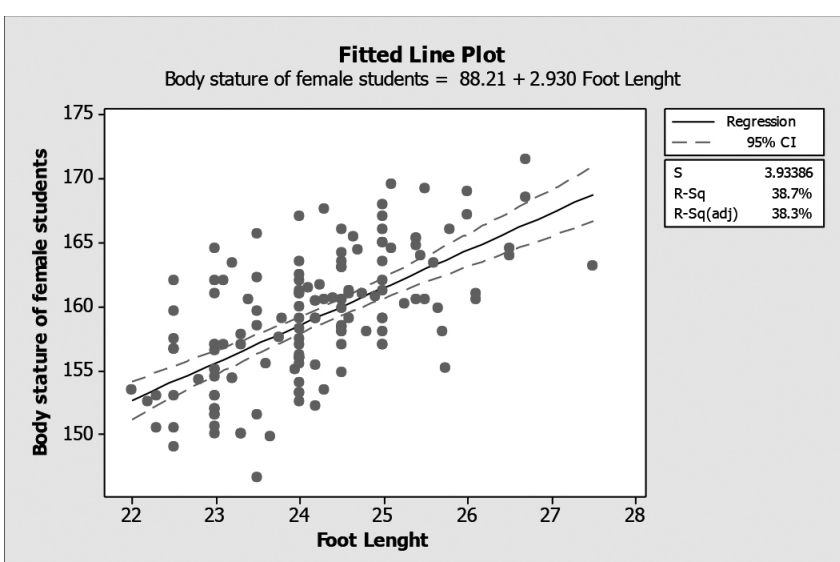

Fig-3. Scatter plot of left foot length and body stature of female subjects.

\section{DISCUSSIONS}

Estimation of stature is of paramount importance in medico-legal examinations and anthropological studies. In the present study, left foot was selected to ensure uniformity. Measurement of left foot was 
taken at a fixed time to rule out diurnal variation. ${ }^{11}$

The results of the present study show that the dimensions of the feet can successfully be used for estimation of stature by law enforcement agencies, forensic scientists and forensic medical examiners. As there is an inherent variability in various populations due to genetic and environmental factors like climate, nutrition etc. hence these formulae are applicable to the population from which the data has been collected. ${ }^{9}$

\section{STUDY SAMPLE, NUMBER AND SEX DISTRIBUTION.}

The present study is carried out on 291 medical students of KEMU, 145 (49.8\%) are males and $146(50.2 \%)$ are females (table 1). Several studies conducted on medical students to estimate stature from foot length. ${ }^{12,13,14,15}$

The sex distribution in the present study is almost similar to the study of Jakhar 2010 that was carried out on 103 medical students, (fifty two $(50.48 \%)$ males, 51 (49.51\%) was female of state of Haryana). The only difference with the present study is that males are slightly more in number than females. The study sample of Sanli ${ }^{13}$ included 1000 medical students, with 536 (53.6\%) male students and 464 (46.6\%) females whereas that of Fawzy ${ }^{15}$ consisted of 50 males Egyptian medical students and research work of Agnihotri ${ }^{12}$ included 125 males and 125 females medical students.

\section{AGE RANGE OF STUDY SUBJECTS}

All the subjects in the present study falls within the age range of $20-25$ years similar to other studies $^{12,13,14}$, that falls within $20-32$ years as a person gains maximum stature at about the age of 20 years and senile changes that may affect stature start after 32 years of age. ${ }^{16}$ As foot length and stature of an individual continued to increase up till complete ossification of long bones therefore the persons below 18 years are usually not included in such studies, however, the results of study of Grivas et $\mathrm{al}^{17}$ in 2008 suggest that stature can be estimated from foot length and weight of a juvenile especially after adjusting for age and sex.

\section{MEAN VALUES OF STATURE AND LEFT FOOT LENGTH}

In the present study, the mean value for stature and left foot length of all subjects was $166.06 \pm$ $9.10 \mathrm{~cm}$ and $25.34 \pm 1.72 \mathrm{~cm}$ respectively tableIV. These findings are almost similar to the earlier mentioned study of Jakhar 2010 where mean stature was $166.33 \pm 9.19 \mathrm{~cm}$, mean left foot length was $24.208 \pm 1.95 \mathrm{~cm}$.

In the present study, males exhibited higher mean values in all the parameters studied than that of females. Table-III showed a significant difference in mean stature of male $(173.16 \pm 6.33)$ and female (159.02 \pm 5.00$)$ and in mean left foot length of male $26.52 \pm 1.419$ and female $24.16 \pm 1.063$ as the $p<0.001$. These results are comparable to the findings of other studies. ${ }^{7,13,18}$

The statistically significant sex differences may be due to the early maturity of girls than boys because of early union of ossification centers in girls, therefore, different equations for males and females are required.

\section{COEFFICIENT CORRELATION BETWEEN STATURE AND LEFT FOOT LENGTH}

A strong significant relationship was found in the present study not only between stature and foot length of all subjects $(r=0.807, p<0.001)$ but also between stature and foot length of male $(r=$ $0.59, p<0.001)$ and female $(r=0.63, p<0.001)$. A comparison of different studies carried out on medical students on estimation of stature from foot length is depicted in table VII, showing a positive correlation is obvious between the foot length and stature in all the studies and ranges from 0.65 to 0.80 .

This shows that foot length is a useful parameter in stature estimation. The value of correlation co-efficient obtained in the present study is inconsistent with several research studies. The difference may be attributed to obvious genetic and possible environmental factors. 


\section{REGRESSION EQUATIONS}

In the present study, regression model was used to estimate the stature from left foot length both for male and female. This is one of the mathematical methods and considered to be better choice than multiplication method. ${ }^{18,19,20,21}$

\begin{tabular}{|c|c|c|c|c|c|c|c|}
\hline Sr. No. & Population & Area & Sex & Regression Equation & $\mathbf{r}$ & Year & Author \\
\hline 1. & Students & Karnataka & $\mathrm{M}$ & $\mathrm{H}=72.40+3.80 * \mathrm{FL}$ & .71 & 1988 & Dr. T. Abraham \\
\hline 2. & M.students & Gujrat & M & $H=75.45+3.64^{\star} F L$ & .65 & 2007 & Patel M Shah \\
\hline 4. & M.students & Sri Lanka & M & $\mathrm{H}=79.042+3.590 * \mathrm{FL}$ & .724 & 2008 & I. llayperuma \\
\hline 5. & M.Students & SriLanka & $\mathrm{F}$ & $H=65.549+3.944^{*} \mathrm{FL}$ & .719 & 2008 & I. Ilayperuma \\
\hline 8. & M.Students & Pune, India & M & $\mathrm{H}=90.0+3.2 \mathrm{FL}$ & 0.645 & 2012 & Sanli \\
\hline 9. & M.Students & Pune, India & $\mathrm{F}$ & $\mathrm{H}=72.8+3.7 \mathrm{FL}$ & 0.702 & 2012 & Sanli \\
\hline
\end{tabular}

A significant high correlation was observed between actual body stature of subjects and estimated body stature $(r=0.807, p<0.001)$, between actual body stature of male subjects and estimated body stature $(r=0.581, p<0.001)$ and between actual body stature of female subjects and estimated body stature $(r=0.622, p<0.001)$. The significant high correlation between actual body stature and estimated body stature from foot length in the present study indicate that foot length is a reliable and strong parameter to estimate stature of an individual and this regression model can be used by forensic experts and law enforcement agencies to establish identity of an individual particularly in case of mass disasters where usually fragmentary remains of bodies are found creating difficulties in determining identity.

A comparison of regression equations of different studies carried out on medical students is mentioned in table-VII.

The different regression equations of different studies showed that these formulae are applicable only to the population from which the data has been collected, due to inherent population variation in these dimensions, which may be attributed to genetic and environmental factor like climate, nutrition etc. Sen \& Ghosh in 2008, recommended that it would be unwise to use same equations for stature estimation in different population groups. ${ }^{9}$ Moreover, these regression equations are also different in males and females because of difference in gender stature and foot length as both parameters have higher values in males so necessitating the different regression equations for both genders.

\section{CONCLUSION}

It is concluded that dimensions of feet has good predictive value in estimation of stature. The correlation coefficient was highest between stature and foot length of both males and females indicating the highest reliability and accuracy in estimating stature in males and females respectively.

\section{SUGGESTIONS}

A more elaborated study for estimation of stature not only on the basis of foot length but on the basis of other parameters like hand length, cranial sutures, toe length etc. should be carried out in collaboration with Anatomy department to establish regression equations for this part of the world facing not only extremes of terrorism in the form of bomb blasts but also earth quakes, floods and air crashes where mass deaths occurred and usually only parts of bodies are available posing problems for determining identification.

Copyright $(28$ April, 2015.

\section{REFERENCES}

1. Krishan K. Determination of stature from foot and its segments in a North Indian population. Am J Forensic 
Med and Pathol. 2008; 29:297-303.

2. Ilayperuma I, Nanayakkara BG, Palahepitiya KN. A model for reconstruction of personal stature based on the measurements of foot length. Galle Med J. 2008; 13: 1 .

3. Agnihotri AK, Shukla S, Purwar B. Determination of sex from the foot measurements. The Internet $J$ Forensic Sci. 2007; 2:1.

4. Fessler DMT, Haley KJ, Lal RD. Sexual dimorphism in foot length proportionate to stature. Ann Human Biology. 2005; 32: 44-59.

5. Srivatava R, Saini V, Rai RK, Pandey S, Tripathi SK. A study of sexual dimorphism in the Femur among North Indians. Journal Forensic Science. 2012; 57(1): $19-23$.

6. Ozaslan, Abdi, Koc, Sermet, Inci, Tugcu, Harun et al. Estimation of stature from body parts. Forensic Sci Int 2003; 132: 40-5.

7. Jakhar JK, Pal V, Paliwal PK. Estimation of stature from measurements of foot length in Haryana Region. J Indian Acad Forensic Med. 2010; 32: 231-3.

8. Krishnan K. Determination of stature from foot and its segments in a north Indian population. Am J Forensic Med Pathol. 2008; 29(4):297-303.

9. Sen J, Ghosh S. Estimation of stature from foot length and foot breadth among the Rajbanshi: An Indigenous population of North Bengal. Forensic Science International. 2008; 181: 51- 56.

10. Khanapurkar S, Radke A. Estimation of stature from the measurement of foot length, hand length and head length in Maharashtra region. 2012; 2: 77-85.

11. Krishan $\mathrm{K}, \mathrm{Vij} \mathrm{K}$. Diurnal Variation of Stature in Three Adults and One Child. Anthropologist. 2007; 9:113-7.
12. Agnihotri AK, Purwar B, Googoolye K, Agnihotri S, Jeebun N. Estimation of stature by foot length. J Forensic Leg Med. 2007; 14(5):279-83.

13. Sanli SG, Kizikanat ED, Boyan N, Ozsahin ET, Bozkir MG, Soames R, Erol H, Oguz O. Stature estimation based on hand length and foot length. Clin Anat. 2005; 18(8):589-96.

14. Patel SM, Shah GV, Patel SV. Estimation of height from measurements of foot length in Gujurat region. J Anat Soc India 2007: 56:25-25.

15. Fawzy IA, Kamal NN. Stature and body weight estimation from various footprint measurements among Egyptian population. J Forensic Sci. 2010; 55: 884-8.

16. Galloway A. Estimating Actual Stature in the Older Individual. J Forensic Sci. 1988; 33:126-36.

17. Grivas TB, Mihas C, Arapaki A, Vasiliadis E. Correlation of foot length with height and weight in school age children. J Forensic Leg Med. 2008;15(2):89-95.

18. Kanchan T, Menezes RG, Moudgil R, Kaur R, Kotian MS, Garg RK. Stature estimation from foot dimensions. Forensic Sci Int. 2008; 179(2-3):241.e 1-5.

19. Raxter MH, Auerbach BM, Ruff CB. Revision of the Fully Technique for estimating statures. American Journal of Physical Anthropology. 2006: 130: 374-381.

20. Krishan K, Kanchan T, Sharma A. Multiplication factor versus regression analysis in stature estimation from hand and foot dimensions. Journal of forensic and legal medicine. 2012; 19: 211-4.

21. Jantz RL, Ousley SD. FRDISC 3.0. Personal computer forensic discriminant functions. Knoxville TN, University of Tennessee; 2005. 


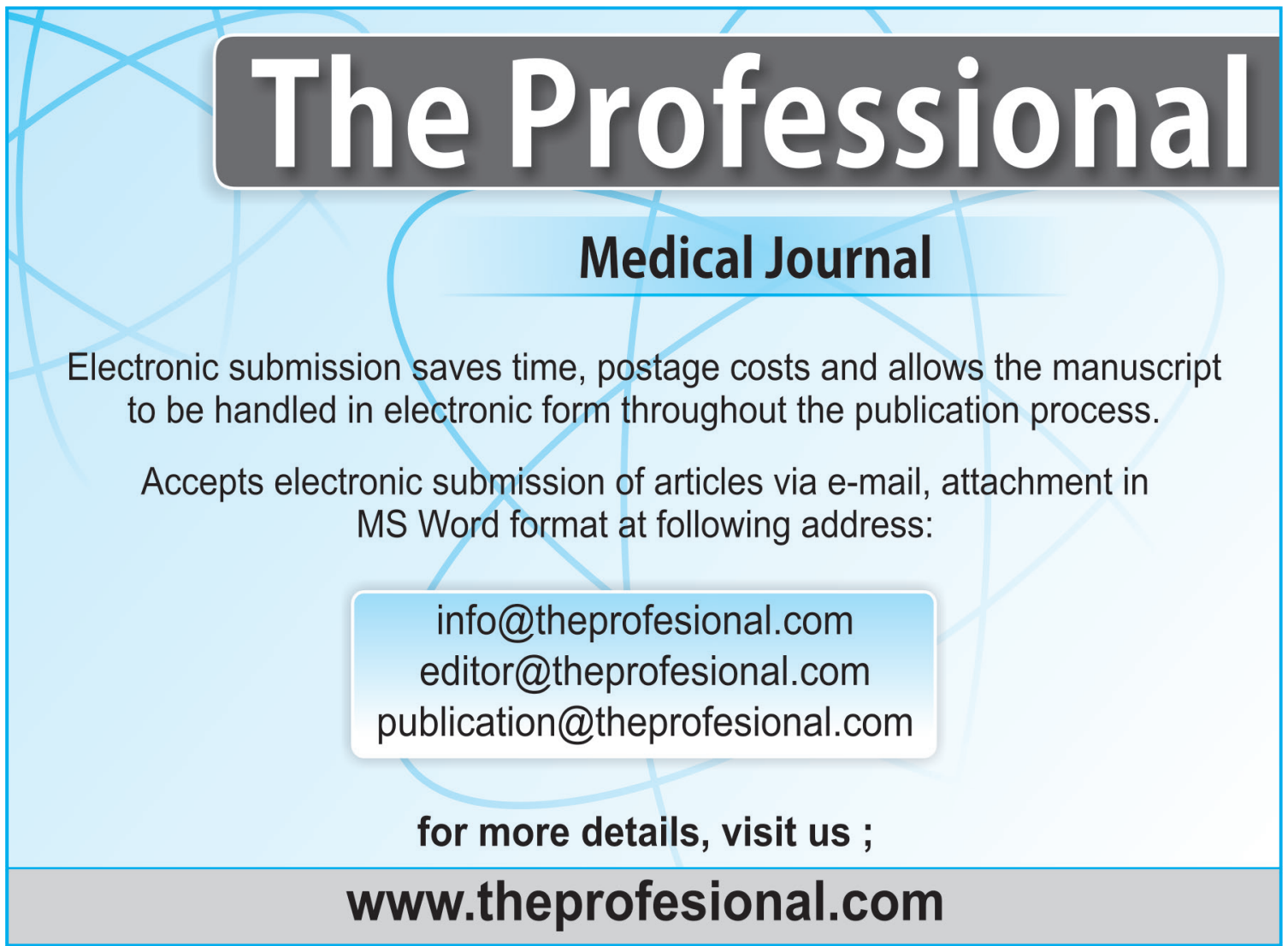

\section{AUTHORSHIP AND CONTRIBUTION DECLARATION}

\begin{tabular}{|c|c|c|c|}
\hline Sr. \# & Author-s Full Name & Contribution to the paper & Author $=$ s Signature \\
\hline 1 & Dr. Arif Rasheed Malik & $\begin{array}{l}\text { Original research work, } \\
\text { principal author }\end{array}$ & \\
\hline 2 & Dr. Nasreen Akhter & $\begin{array}{l}\text { Help in collecting data, } \\
\text { literature. }\end{array}$ & \\
\hline 3 & Dr. Riasat Ali & $\begin{array}{l}\text { Help in collecting data, } \\
\text { literature. }\end{array}$ & \\
\hline 4 & Dr. Raan'A Farrukh & Forensic analyst. & Letande \\
\hline 5 & Prof. Dr. Khalid Aziz & $\begin{array}{l}\text { Research supervisor, guide } \\
\text { about statistical analysis. }\end{array}$ & \\
\hline
\end{tabular}

